\title{
Kuminanviljelyn taloudellinen kilpailukyky
}

Timo Karhula

MTT Taloustutkimus, Latokartanonkaari 9,00790 Helsinki, timo.karhula@mtt.fi

\section{Tiivistelmä}

Kiinnostus kuminanviljelyyn on lisääntynyt koko viime vuosikymmenen ajan Suomessa. Vuonna 2011 kuminaa viljeltiin noin 20700 hehtaarilla, viljelyala kasvoi vuodesta 2010 peräti $40 \%$. Kuminaa tuotettiin tällöin noin 8,5 miljoonaa kiloa, jolloin sen markkinahintaiseksi tuotoksi muodostui noin viisi miljoonaa euroa. Vuonna 2011 kuminan markkinahintaiseksi tuotoksi arvioidaan syntyvän noin 8,4 miljoonaa euroa.

Tämä tutkimus liittyy MTT:n, Agropolis Oy:n ja ProAgrian "Ylivoimainen kuminaketju" -yhteistutkimushankkeeseen. Tässä esitetään hankkeen talousosion ensimmäisiä alustavia tuloksia, joissa arvioidaan kuminanviljelyn taloudellista kilpailukykyä vertailukasveihin, rehuohraan ja rypsiin nähden.

Tulosten mukaan kuminanviljely on taloudellisesti kannattavampaa kuin vertailukasvien viljely. Tulokset osoittavat myös, että millään tutkimuksessa mukana olleella viljelykasvilla tuotot eivät riitä käytetyillä oletuksilla kattamaan tuotantokustannuksia. Tuottojen ja tuotantokustannusten erotuksena syntyy tällöin tappiota. Kuminalla tuotot yltävät kuitenkin lähimmäs tuotantokustannuksia, jolloin syntyvän tappion määrä on tutkittavista viljelykasveista pienin. Kuminalla on siten vertailukasveihin nähden parempi mahdollisuus päästä kiinni kannattavan tuotannon edellytyksiin, esimerkiksi keskisatoa nostamalla. Kuminanviljelyssä juuri satovarmuutta (= hyvä satotaso vuodesta toiseen) voidaan pitää yhtenä avaintekijänä kannattavan tuotannon rajan saavuttamiseksi, koska kuminan satotasot ovat olleet alhaisia ja vuosien välinen vaihtelu erittäin suurta.

Asiasanat: kumina, kilpailukyky, kannattavuus, tuotantokustannus 


\section{Johdanto}

Suomessa kiinnostus kuminanviljelyyn on lisääntynyt koko viime vuosikymmenen ajan. Vuonna 2011 kuminaa viljeltiin noin 1400 tilalla, yhteensä 20700 hehtaarilla. Vuodesta 2010 viljelyala lisääntyi peräti noin

$40 \%$ eli 7800 hehtaaria. Alueellisesti kuminaa viljeltiin eniten Etelä-Pohjanmaan (n. 4000 ha), Pohjanmaan (n. 3000 ha), Hämeen, Uudenmaan ja Varsinais-Suomen (kussakin n. 2000 ha) ELY keskusten alueella. Ainoastaan Lapissa kuminaa ei viljelty lainkaan vuonna 2011.

Suomessa tuotettiin kuminaa noin 8,5 miljoonaa kiloa vuonna 2010. Kuminan markkinahintaiseksi tuotoksi muodostui tällöin noin viisi miljoonaa euroa. Vuonna 2011 kuminan markkinahintaiseksi tuotoksi arvioidaan muodostuvan noin 8,4 miljoonaa euroa.

Kuminan keskisato oli $660 \mathrm{~kg} / \mathrm{ha}$ vuonna 2010. Keskisato on kuitenkin vaihdellut ajan mittaan hyvin paljon, esimerkiksi vuonna 2009 keskisato oli vain noin $300 \mathrm{~kg} / \mathrm{ha}$. Tällä hetkellä suomalainen kuminantuottaja viljelee keskimäärin 15 hehtaaria kuminaa viljelykierrossaan, joten tilakohtaiset kuminan tuotantomäärät ovat vielä keskimäärin melko pieniä. Suurimmilla kotimaisilla kuminantuottajilla viljelyala on kuitenkin jo 150 hehtaaria.

Kuminan lähes koko sato viedään ulkomaille ja vain pieni osa käytetään Suomessa. Suomalaisella kuminalla on maailmalla noin neljänneksen markkinaosuus. Tärkein markkina-alue on Keski-Eurooppa, jossa suurimmat vientimaat ovat Hollanti ja Saksa. Suurin osa kuminansiemenistä käytetään vientimaissa joko kokonaisina tai jauhettuna elintarvikkeiden maustamiseen. Osasta siemeniä tislataan öljyä, jota käytetään aromiaineena kosmetiikka- ja lääketeollisuudessa (Tietosarka 1/2011).

MTT:1lä, Agropolis Oy:llä ja Pro Agrialla on käynnissä yhteinen EU-rahoitteinen ”Ylivoimainen kuminaketju" -hanke, jolla pyritään parantamaan kotimaisen kuminan viljelyvarmuutta ja laatua. Tässä esitetään tämän hankkeen talousosion ensimmäisiä alustavia tuloksia, lopulliset tulokset valmistuvat vuonna 2013. Lisätietoja hankkeesta löytyy: www.agronet.fi/kumina.

\section{Aineisto ja menetelmä}

Tässä tutkimuksessa laadittiin katetuotto- ja tuotantokustannuslaskelmia kuminalle, jotta kuminanviljelyn taloudellista kilpailukykyä päästään arvioimaan vertailukasveihin nähden. Vertailukasveiksi valittiin rehuohra ja kevätrypsi. Vertailukasvien osalta laskelmien pohjana käytettiin ProAgrian mallilaskelmia (Tuottopehtori). Laskelmat laadittiin AB-tukialueen tuin ja hintoina käytettiin vuoden 2011 hintoja heinäkuuhun saakka.

Laskentamallit ovat teoreettisia, eikä niitä ole vielä kytketty esimerkiksi toteutuneisiin satotasoihin tai tilatason viljelykiertoihin. Laskentamallit laadittiin alkuvaiheessa sekä kuminalle että vertailukasveille kolmella eri satotaso-oletuksella (Taulukko 1). Koska kumina on monivuotinen kasvi (oletus: kasvuston perustamisvuosi + 2 satovuotta), laadittiin sille laskelma, jossa tulokset esitetään satovuotta kohden, jossa perustamisvuosi on huomioitu.

Taulukko 1. Laskentaoletuksia.

\begin{tabular}{lcccccccccc}
\hline & Yksikkö & \multicolumn{3}{c}{ Rehuohra } & \multicolumn{3}{c}{ Rypsi } & \multicolumn{3}{c}{ Kumina satovuonna } \\
Laskentamalli & & $\mathbf{A}$ & $\mathbf{B}$ & $\mathbf{C}$ & $\mathbf{A}$ & $\mathbf{B}$ & $\mathbf{C}$ & $\mathbf{A}$ & $\mathbf{B}$ & $\mathbf{C}$ \\
\hline Sadon määrä & $\mathrm{t} / \mathrm{ha}$ & 3 & 4 & 5 & 1 & 1,5 & 2 & 0,5 & 0,8 & 1 \\
Tuotot & & & & & & & & & \\
Sadon hinta - rahti & $€ / \mathrm{t}$ & 148 & 148 & 148 & 434 & 434 & 434 & 587 & 587 & 587 \\
Tuet & $€ / \mathrm{ha}$ & 604 & 604 & 604 & 608 & 608 & 608 & 744 & 744 & 744 \\
Keskeiset kustannukset & & & & & & & & & \\
Siemenen hinta & $€ / \mathrm{t}$ & 317 & 322 & 327 & 5100 & 5100 & 5100 & 2200 & 2200 & 2200 \\
Siemenen määrä & $\mathrm{kg} / \mathrm{ha}$ & 205 & 205 & 205 & 9 & 9 & 9 & 7 & 7 & 7 \\
Lannoitteen hinta & $€ / \mathrm{t}$ & 480 & 480 & 480 & 430 & 430 & 430 & 500 & 500 & 500 \\
Lannoitteen määrä & $\mathrm{kg} / \mathrm{ha}$ & 260 & 350 & 440 & 500 & 600 & 700 & 200 & 267 & 300 \\
Kalkitus & $€ /$ ha & 0 & 10 & 21 & 0 & 10 & 21 & 0 & 14 \\
Kasvinsuojelukustannus & $€ /$ ha & 52 & 52 & 52 & 109 & 109 & 109 & 73 & 73 \\
Energia, poltto- ja voiteluaineet & $€ /$ ha & 128 & 148 & 169 & 91 & 101 & 112 & 35 & 40 \\
Työn hinta & $€ /$ ha & 179 & 179 & 179 & 179 & 179 & 179 & 89 & 107 \\
Konekustannus & $€ /$ ha & 359 & 359 & 359 & 393 & 393 & 393 & 393 & 393 & 393
\end{tabular}




$€ /$ ha $\quad 146$

\section{Tulokset}

Tulokset esitetään tässä seuraavilla satotaso-oletuksilla: rehuohra $4 \mathrm{t} / \mathrm{h}$, rypsi $1,5 \mathrm{t} / \mathrm{ha}$ ja kumina $0,8 \mathrm{t} / \mathrm{ha}$ (Taulukko 1). Tulosten mukaan kuminan ja vertailukasvien tuotoiksi muodostuu näillä satotaso-oletuksilla noin $1200 €$ /ha (Kuva 1). Tuotettua satokiloa kohden tuotot vaihtelevat kuitenkin huomattavasti enemmän, riippuen kasvista, satotaso-oletuksesta, tuottajahinnasta ja tuista. Rehuohralla tuottoja syntyy tuotettua satokiloa kohden yhteensä $0,32 € / \mathrm{kg}$, rypsillä $0,85 € / \mathrm{kg}$ ja kuminalla $1,54 € / \mathrm{kg}$. Rehuohralla ja rypsillä tukien osuus tuotoista on noin $50 \%$ ja kuminalla $60 \%$. Loppuosa tuotoista muodostuu sadon myyntituloista.

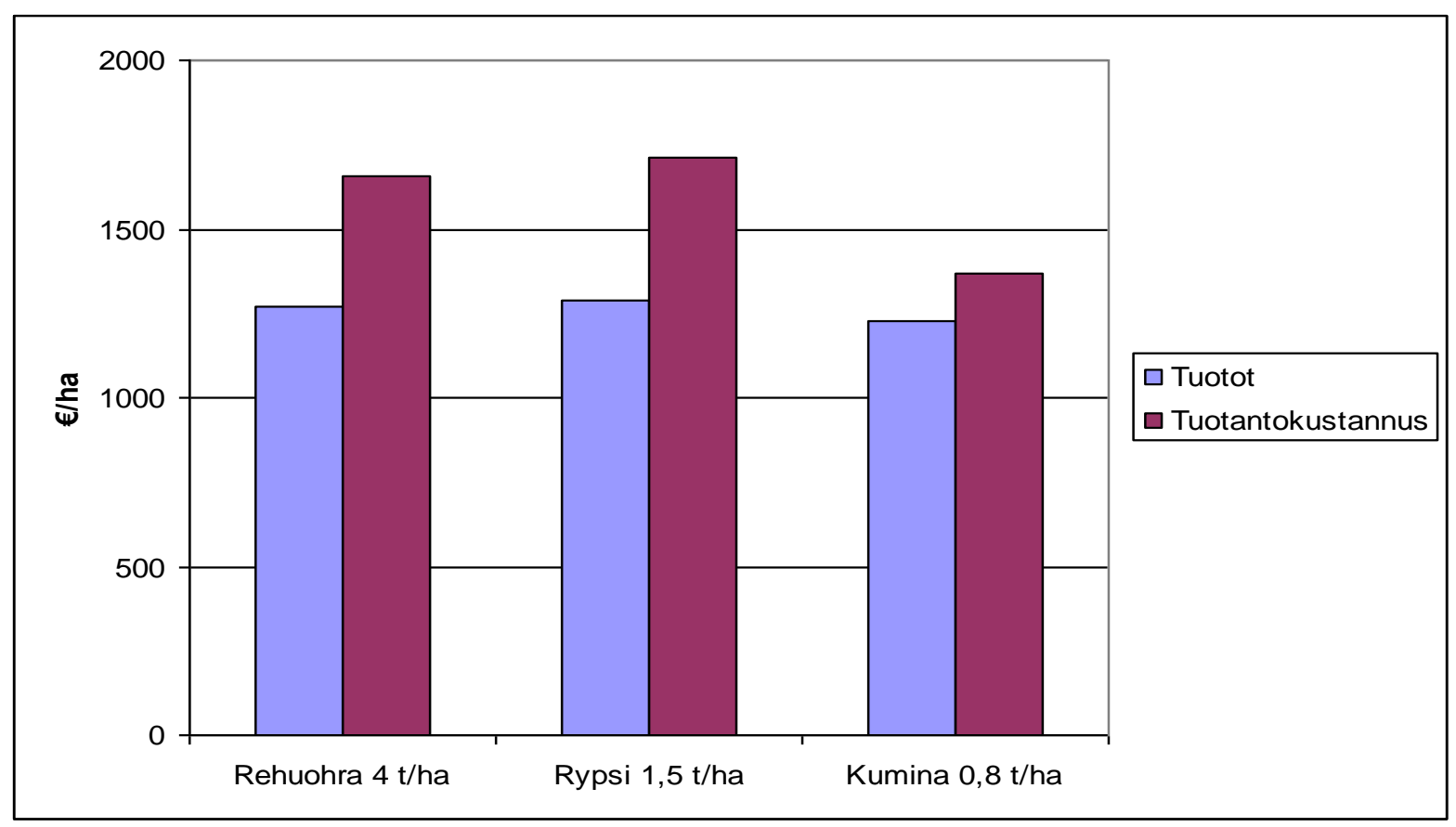

Kuva 1. Kuminan ja vertailukasvien tuotot ja tuotantokustannus satotaso-oletuksilla (€/ha).

Tuotantokustannukset ovat rehuohralla noin $1660 € /$ ha, rypsillä noin $1720 € /$ ha ja kuminalla $1370 € /$ ha (Kuva 1). Kuminan tuotantokustannukset ovat kasveista alhaisimmat käytetyillä satotaso-oletuksilla. Tuotettua satokiloa kohden rehuohralla syntyy tuotantokustannuksia $0,41 € / \mathrm{kg}$, rypsillä $1,14 € / \mathrm{kg}$ ja kuminalla $1,70 € / \mathrm{kg}$. Muuttuvien kustannusten osuus rehuohralla ja rypsillä on noin $36 \%$ ja kuminalla 26 $\%$ tuotantokustannuksesta. Työkustannuksen osuus rehuohralla ja rypsillä on $10 \%$ ja kuminalla $8 \%$ tuotantokustannuksesta. Loppuosuus tuotantokustannuksesta on korvausta kiinteälle omaisuudelle ja tuotantoon sidotulle pääomalle.

Kuminalla ja vertailukasveilla tuotot eivät riitä kattamaan viljelystä aiheutuneita tuotantokustannuksia. Tällöin syntyy yrittäjäntappiota. Laskelmissa käytetyillä satotaso-oletuksilla ja hintasuhteilla vertailukasveista rypsillä syntyy eniten tappiota, noin $420 € /$ ha. Rehuohralla syntyvän tappion määrä on hieman pienempi, noin $380 € / \mathrm{ha}$. Kuminalla yrittäjäntappiota syntyy käytetyllä $800 \mathrm{~kg} / \mathrm{ha}$ satotaso-oletuksella noin $140 € /$ ha, mikä on tutkittavista viljelykasveista vähiten (Kuva 2). 


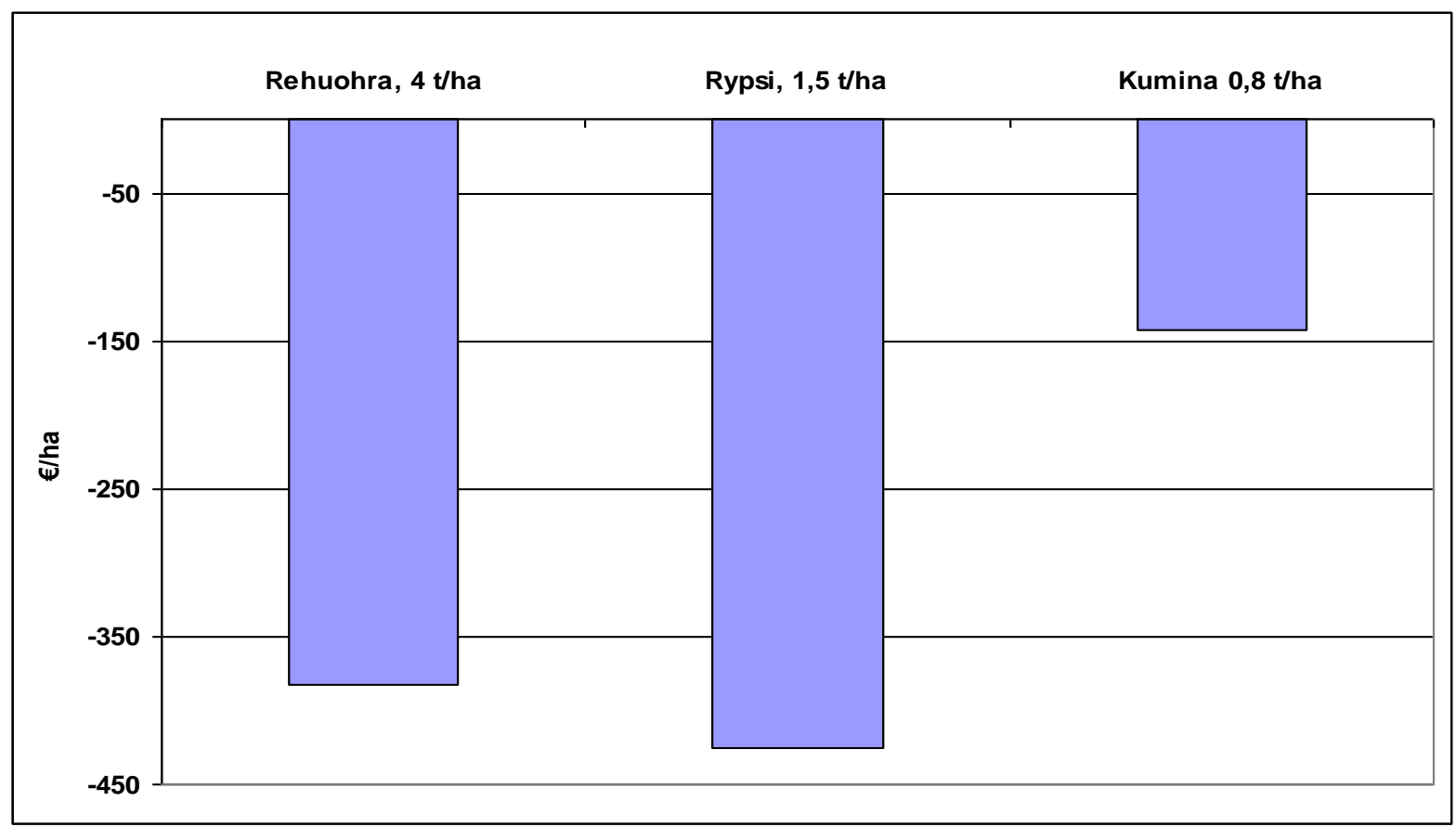

Kuva 2. Yrittäjäntappio kuminalla ja vertailukasveilla satotaso-oletuksilla (€/ha).

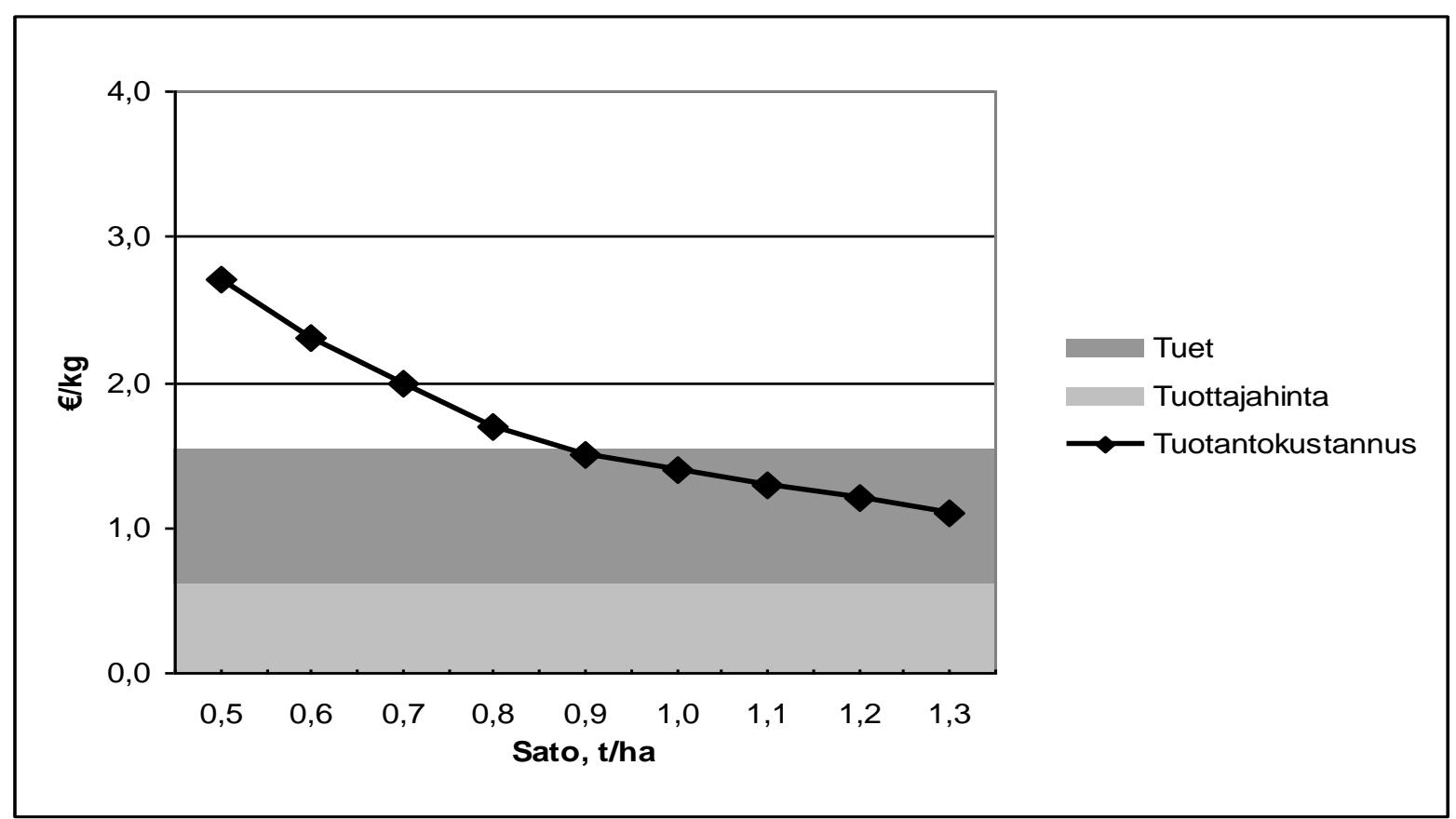

Kuva 3. Kuminan tuotantokustannuksen $(€ / \mathrm{kg})$ kehittyminen satotaso-oletuksien (t/ha) mukaan.

Jotta kuminantuotannossa kannattavan tuotannon raja saavutettaisiin, pitäisi tuotantokustannusten ja tuottojen (tuet + sadon myyntitulot) olla yhtä suuria. Tällöin ei syntyisi tappiota, mutta ei vielä voittoakaan. Alustavien tulosten mukaan kuminan keskisadon pitäisi olla vähintään $900 \mathrm{~kg} / \mathrm{ha}$, jotta taloudellisesti kannattavan tuotannon raja saavutettaisiin (Kuva 3). Esimerkiksi tuottajahinnan laskeminen, muiden tekijöiden pysyessä ennallaan, siirtäisi kannattavan tuotannon rajaa kohti korkeampia satotasoja. Toisaalta hinnan nouseminen laskisi satotasotavoitetta kannattavan tuotannon saavuttamiseksi. 


\section{Johtopäätökset}

Kuminanviljelyssä tuilla on merkittävä rooli, sillä sadon myyntitulojen osuudeksi jää vain $40 \%$ tuotoista, kun vertailukasveilla osuus on $50 \%$. Kustannuspuolella kiinteät kustannukset ovat kuminanviljelyssä huomionarvoisessa asemassa, koska perustamisvuonna ne rasittavat tuotantoa muuttuvien kustannusten rinnalla, vaikka satoa ei saada lainkaan. Tähän taloudelliseen rasitteeseen voitaisiin hakea ratkaisua esimerkiksi kasvattamalla kuminaa perustamisvuonna varsinaisen satokasvin (esim. ohra) aluskasvina.

Tulosten mukaan kuminanviljely on kannattavampaa kuin vertailukasvien viljely. Tulokset kuitenkin osoittavat, että millään tutkimuksessa mukana olleella kasvilla tuotot eivät riitä käytetyillä oletuksilla kattamaan täysin tuotantokustannuksia. Tuottojen ja tuotantokustannusten erotuksena syntyy tällöin yrittäjäntappiota. Kuminalla tuotot yltävät kuitenkin lähimmäs tuotantokustannuksia, jolloin syntyvän tappion määrä on kasveista alhaisin.

Kuminalla on vertailukasveihin nähden parempi mahdollisuus päästä kiinni kannattavaan tuotantoon esimerkiksi satotasoja nostamalla, koska jo lähtötilanteessa kuminanviljelyn kannattavuus on vertailukasveja parempi. Kuminanviljelyssä satovarmuudella (= hyvä satotaso vuodesta toiseen) on avainasema kannattavan tuotannon saavuttamiseksi, sillä kuminan keskisadot ovat olleet alhaisia ja vuosien välinen vaihtelu erittäin suurta. Satotason suuret vaihtelut lyhyellä aikavälillä lisäävätkin taloudellista epävarmuutta kuminantuotannossa.

Kuminalla sadon määrän samansuhteinen pieneneminen tai kasvaminen ei välttämättä tuota samansuuruista kannattavuuden muutosta. Satomäärän pienentyminen saattaa laskea kannattavuutta enemmän kuin sadon määrän samansuhteinen kasvaminen nostaa sitä. Varsinkin korkeissa satomäärissä kustannukset alkavat vakioitua, jolloin sadon lisäyksellä ei enää välttämättä saada aikaan merkittäviä kustannussäästöjä eikä siten kannattavuuden parantumista. Lisäksi suureen satoon liittyy aina myös suuret tappion mahdollisuudet. Jos esimerkiksi sato joudutaan myymään alhaisella hinnalla, muodostuu tuotantokustannuksen ja tuottajahinnan erotus suureksi, jolloin tappion syntymistä ei voida välttää.

Kun euromääräiset tuotot ovat tuotantokustannuksia suuremmat, voidaan yritystoimintaa pitää kannattavana eli taloudellisille tavoitteille saadaan asetetut korvausvaateet. Kuminalla näistä taloudellista tavoitteista joudutaan tinkimään, koska kannattavan tuotannon rajaa ei ainakaan vielä täysin saavuteta. Taloudellisten tavoitteiden asettaminen riippuu kuitenkin siitä, minkälaisen korvauksen kuminanviljelijä haluaisi työlleen ja tuotantoon sidotulle pääomalleen.

\section{Kirjallisuus}

Tietosarka 1/2011. Kuminan viljely yleistyy Suomessa. Maa- ja metsätalousministeriön tietopalvelukeskus. Saatavissa: http://tike.multiedition.fi/tike/tietosarka/2011/helmikuu/kumina.php. 